\title{
Front Matter: Volume 6501
}

, "Front Matter: Volume 6501," Proc. SPIE 6501, Sensors, Cameras, and Systems for Scientific/Industrial Applications VIII, 650101 (6 March 2007); doi: 10.1117/12.729095

SPIE. Event: Electronic Imaging 2007, 2007, San Jose, CA, United States 


\section{Sensors, Cameras, and Systems for Scientific/Industrial Applications VIII}

Morley M. Blouke

Editor

30 January-1 February 2007

San Jose, California, USA

Sponsored and Published by

IS\&T-The Society for Imaging Science and Technology

SPIE-The International Society for Optical Engineering 
The papers included in this volume were part of the technical conference cited on the cover and title page. Papers were selected and subject to review by the editors and conference program committee. Some conference presentations may not be available for publication. The papers published in these proceedings reflect the work and thoughts of the authors and are published herein as submitted. The publishers are not responsible for the validity of the information or for any outcomes resulting from reliance thereon.

Please use the following format to cite material from this book:

Author(s), "Title of Paper," in Sensors, Cameras, and Systems for Scientific/Industrial Applications VIII, edited by Morley M. Blouke, Proceedings of SPIE-IS\&T Electronic Imaging, SPIE Vol. 6501, Article CID Number (2007).

ISSN 0277-786X

ISBN 9780819466143

Copublished by

SPIE-The International Society for Optical Engineering

P.O. Box 10, Bellingham, Washington 98227-0010 USA

Telephone 1 360/676-3290 (Pacific Time) · Fax 1 360/647-1445

http://www.spie.org

and

IS\&T-The Society for Imaging Science and Technology

7003 Kilworth Lane, Springfield, Virginia, 22151 USA

Telephone 1 703/642-9090 (Eastern Time) · Fax 1 703/642-9094

http://www.imaging.org

Copyright @ 2007, The Society of Photo-Optical Instrumentation Engineers and The Society for Imaging Science and Technology.

Copying of material in this book for internal or personal use, or for the internal or personal use of specific clients, beyond the fair use provisions granted by the U.S. Copyright Law is authorized by SPIE and IS\&T subject to payment of copying fees. The Transactional Reporting Service base fee for this volume is $\$ 18.00$ per article (or portion thereof), which should be paid directly to the Copyright Clearance Center (CCC), 222 Rosewood Drive, Danvers, MA 01923. Payment may also be made electronically through CCC Online at http://www.copyright.com. Other copying for republication, resale, advertising or promotion, or any form of systematic or multiple reproduction of any material in this book is prohibited except with permission in writing from the publisher. The CCC fee code is 0277$786 \times / 07 / \$ 18.00$

Printed in the United States of America. 


\section{Contents}

vii Conference Committee

\section{SESSION 1 CCD IMAGERS}

650102 Evaluation of the 111-megapixel high speed high resolution CCD [6501-01]

K. Boggs, R. Bredthaver, G. Bredthaver, Semiconductor Technology Associates Inc. (USA)

650103 Computation of dark frames in digital imagers [6501-02]

R. Widenhorn, Portland State Univ. (USA) and Digital Clarity Consultants (USA); A. Rest, Cerro Tololo Inter-American Observatory (USA); M. M. Blouke, Ball Aerospace \& Technologies Corp. (USA); R. L. Berry, Digital Clarity Consultants (USA); E. Bodegom, Portland State Univ. (USA) and Digital Clarity Consultants (USA)

650104 A novel pixel structure for $\mathbf{2} \boldsymbol{\mu m}$ square pixel IT-CCD [6501-03] G. Sakoda, M. Sato, D. Sugimoto, K. Maari, S. Miyazawa, T. Takeda, M. Kimura, T. Fujioka, Sony Corp. (Japan); M. Fujishima, Y. Kani, Sony LSI Design Inc. (Japan); H. Kanbe, Sony Corp. (Japan)

650105 Simulation for estimating smear noise and sensitivity of CCD image sensors having square pixels cells less than 2.0 um [6501-04]

K. Kikuchi, S. Miyazawa, Y. Uchida, H. Kamata, T. Hirayama, Sony Corp. (Japan)

650106 Development of fully depleted scientific CCDs for astronomy [6501-05]

K. Boggs, R. Bredthaver, Semiconductor Technology Associates Inc. (USA); M. Lesser, Univ. of Arizona (USA)

650107 Orthogonal transfer arrays for the Pan-STARRS gigapixel camera [6501-41]

B. E. Burke, MIT Lincoln Lab. (USA); J. L. Tonry, Univ. of Hawaii (USA); M. J. Cooper,

P. E. Doherty, A. H. Loomis, D. J. Young, T. A. Lind, MIT Lincoln Lab. (USA); P. Onaka, Univ. of Hawaii (USA); D. J. Landers, P. J. Daniels, J. L. Daneu, MIT Lincoln Lab. (USA)

Pagination: Proceedings of SPIE follow an e-First publication model, with papers published first online and then in print and on CD-ROM. Papers are published as they are submitted and meet publication criteria. A unique, consistent, permanent citation identifier (CID) number is assigned to each article at the time of the first publication. Utilization of CIDs allows articles to be fully citable as soon they are published online, and connects the same identifier to all online, print, and electronic versions of the publication.

SPIE uses a six-digit CID article numbering system in which:

- The first four digits correspond to the SPIE volume number.

- The last two digits indicate publication order within the volume using a Base 36 numbering system employing both numerals and letters. These two-number sets start with 00, 01, 02, 03, 04, 05, 06, 07, 08, 09, OA, OB ... 0Z, followed by 10-1Z, 20-2Z, etc.

The CID number appears on each page of the manuscript. The complete citation is used on the first page, and an abbreviated version on subsequent pages. 
650108 Improvement in photoelectric conversion efficiency of red light in HARP film [6501-06] T. Matsubara, Y. Ohkawa, K. Miyakawa, S. Suzuki, M. Kubota, N. Egami, K. Tanioka, NHK Science \& Technical Research Labs. (Japan); K. Ogusu, A. Kobayashi, T. Hirai, T. Kawai, Hamamatsu Photonics K.K. (Japan)

650109 Bifocal liquid lens zoom objective for mobile phone applications [6501-07] F. C. Wippermann, P. Schreiber, A. Bräuer, Fraunhofer Institute for Applied Optics and Precision Engineering (Germany); P. Craen, Varioptic SA (France)

65010A The intermediate size direct detection detector for electron microscopy [6501-08] L. Jin, A.-C. Milazzo, Univ. of California, San Diego (USA); S. Kleinfelder, S. Li, Univ. of California, Irvine (USA); P. Leblanc, F. Duttweiler, J. C. Bouwer, S. T. Peltier, M. Ellisman, N.-H. Xuong, Univ. of California, San Diego (USA)

65010B A novel image acquisition system using the optical-multiplex system [6501-09] T. Narabu, Sony Corp. (Japan)

65010D Position detection with hyperacuity using artificial compound eyes [6501-11] A. Brückner, J. Duparré, A. Bräuer, Fraunhofer Institute for Applied Optics and Precision Engineering (Germany); A. Tünnermann, Fraunhofer Institute for Applied Optics and Precision Engineering (Germany) and Friedrich-Schiller-Univ. Jena (Germany)

65010E High-dynamic-range video for photometric measurement of illumination [6501-12] J. Unger, S. Gustavson, Linköping Univ. (Sweden)

65010F Thermal-imaging-based procedures for special concretes characterization [6501-14] G. Bonifazi, M. Animali, L. Damiani, Univ. degli Studi di Roma La Sapienza (Italy)

\section{SESSION 3 CMOS SENSORS}

$65010 \mathrm{G}$ Shared transistor architecture with diagonally connected pixels for a CMOS image sensor [6501-15]

Y. Kudoh, F. Koga, T. Abe, H. Taniguchi, M. Sato, H. Ishiwata, S. Ooki, R. Suzuki, H. Mori, Sony Corp. (Japan)

65010H Image sensor for object detection using modulated light [6501-16]

H. Taruki, A. Ohno, F. Ono, T. Hamamoto, Tokyo Univ. of Science (Japan); T. Sasaki, T. Shirai, M. Sakai, The Nippon Signal Co., Ltd. (Japan)

650101 Linear-logarithmic image sensor with low noise and no flickers [6501-17] S. Miyatake, M. Kusuda, T. Iwamoto, T. Katagiri, K. Kamon, K. Sato, Y. Serita, Konica Minolta Technology Ctr., Inc. (Japan)

65010K Distance detective small camera module [6501-19]

I. Oyama, T. lijima, K. Imada, S. Tamaki, T. Suenaga, N. Imamura, T. Ota, M. Suzuki,

M. Nagashima, Matsushita Electric Industrial Co., Ltd. (Japan) 
65010L A digital high-dynamic-range CMOS image sensor with multi-integration and pixel readout request [6501-20]

A. Guilvard, J. Segura, STMicroelectronics (France); P. Magnan, P. Martin-Gonthier,

CIMI/Supaero (France)

65010N Demonstration of a low-voltage three-transistor-per-pixel CMOS imager based on a pulsewidth-modulation readout scheme employed with a one-transistor in-pixel comparator [6501-22]

S. Shishido, I. Nagahata, T. Sasaki, K. Kagawa, M. Nunoshita, J. Ohta, Nara Institute of Science and Technology (Japan)

650100 A 960-fps sub-sampling object extraction CMOS image sensor with 12-bit column parallel ADCs and ALUs [6501-23]

Y. Motohashi, T. Kubo, H. Kanto, T. Tate, S. Sugawa, Tohoku Univ. (Japan)

65010P A temperature resistant wide dynamic range CMOS image sensor [6501-24]

K. Mizobuchi, S. Adachi, T. Yamashita, S. Okamura, H. Oshikubo, Texas Instruments Japan

(Japan); N. Akahane, S. Sugawa, Tohoku Univ. (Japan)

\section{SESSION 4 SYSTEMS AND APPLICATIONS II}

65010Q Characterization and system modeling of a 5-Mpixel CMOS array [6501-42]

K. Cabanas-Holmen, D. Dorn, C. Tesdahl, Pelco (USA)

65010R Low cost optical polarization sensor [6501-26]

D. P. Baxter, J. M. Raynor, J.-L. Jaffard, STMicroelectronics (United Kingdom); D. Renshaw, The Univ. of Edinburgh (United Kingdom)

650105 A diffractive multispectral image sensor with on- and off-die signal processing and on-die optics in 0.18-micron CMOS [6501-27]

C. Thomas, R. Hornsey, York Univ. (Canada)

65010T Diffraction grating lens array [6501-28]

T. Korenaga, T. Ando, S. Moriguchi, F. Takami, Y. Takasu, S. Nishiwaki, M. Suzuki,

M. Nagashima, Matsushita Electric Industrial Co., Ltd. (Japan)

\section{SESSION $5 \quad$ NONDESTRUCTIVE TESTING}

$65010 \mathrm{U}$ Critical assessment of the integrity of thin organic films by shearography [6501-29]

K. Habib, Kuwait Institute for Scientific Research (Kuwait)

65010W Development of a wavelength-changeable multiband color-mixing imaging device and its application [6501-40]

F. Ding, Y.-R. Chen, K. Chao, D. E. Chan, USDA Agricultural Research Service (USA)

\section{POSTER SESSION}

65010Y Qualitative measurement of average index profile of symmetrical microstructured optical fiber from microscopic imaging [6501-32]

E. Saucedo, V. P. Minkovich, Ctr. de Investigaciones en Optica, A.C. (Mexico) 
650102 A practicable method for color classification using low-cost remission/reflection sensors [6501-33]

R. Hauser, Carinthia Univ. of Applied Sciences (Austria); I. Ibraheem, Carinthian Tech Research (Austria); C. V. Madritsch, N. Kabirpanthi, Carinthia Univ. of Applied Sciences (Austria); D. Römhild, D. Starke, CiS, Institut für Mikrosensorik GmbH (Germany);

V. Mannheim, Carinthia Tech Research (Austria); W. Schwab, Carinthia Univ. of Applied Sciences (Austria); J. Krohn, J. Randa, Haukeland Univ. Hospital (Norway); T. Klinger, Carinthia Univ. of Applied Sciences (Austria)

650110 A CMOS vision chip for a contrast-enhanced image using a logarithmic APS and a switchselective resistive network [6501-34]

J.-S. Kong, S.-H. Kim, D.-K. Sung, S.-H. Seo, J.-K. Shin, Kyungpook National Univ. (South Korea)

650111 Highly sensitive and area-efficient CMOS image sensor using a PMOSFET-type photodetector with a built-in transfer gate [6501-35]

S.-H. Seo, K.-D. Kim, J.-S. Kong, J.-K. Shin, P. Choi, Kyungpook National Univ. (South Korea)

650112 Microscopic x-ray imaging system for biomedical applications using synchrotron radiation [6501-37]

K. Umetani, Japan Synchrotron Radiation Research Institute (Japan); M. Kobatake,

A. Yamamoto, T. Yamashita, S. Imai, Kawasaki Medical School (Japan)

650114 Sensor for moving foreground detection: an address-event-based embedded system [6501-39]

N. Milosevic, P. Schön, Austrian Research Ctrs. GmbH (Austria)

Author Index 


\title{
Conference Committee
}

\author{
Symposium Chairs \\ Michael A. Kriss, Consultant (USA) \\ Robert A. Sprague, Consultant (USA) \\ Conference Chair
}

Morley M. Blouke, Ball Aerospace \& Technologies Corporation (USA)

Program Committee

Erik Bodegom, Portland State University (USA) and Digital Clarity

Consultants (USA)

Terrence S. Lomheim, The Aerospace Corporation (USA)

Kevin J. Matherson, Hewlett-Packard Company (USA)

Gloria G. Putnam, Eastman Kodak Company (USA)

Alice L. Reinheimer, e2v technologies inc. (USA)

Nobukazu Teranishi, Matsushita Electric Industrial Company, Ltd. (Japan)

Penny G. Warren, Ball Aerospace \& Technologies Corporation (USA)

Orly Yadid-Pecht, University of Calgary (Canada)

\section{Session Chairs}

$1 \quad C D$ Imagers

Morley M. Blouke, Ball Aerospace \& Technologies Corporation (USA)

David A. Dorn, Pelco (USA)

2 Applications and Systems I

Erik Bodegom, Portland State University (USA) and Digital Clarity

Consultants (USA)

3 CMOS Sensors

Alice L. Reinheimer, e2v technologies inc. (USA)

$4 \quad$ Systems and Applications II

Barry E. Burke, MIT Lincoln Laboratory (USA)

$5 \quad$ Nondestructive Testing

Barry E. Burke, MIT Lincoln Laboratory (USA) 
SPIE-IS\&T/ Vol. $6501650101-8$

Downloaded From: https://www.spiedigitallibrary.org/conference-proceedings-of-spie on 26 Apr 2023 Terms of Use: https://www.spiedigitallibrary.org/terms-of-use 